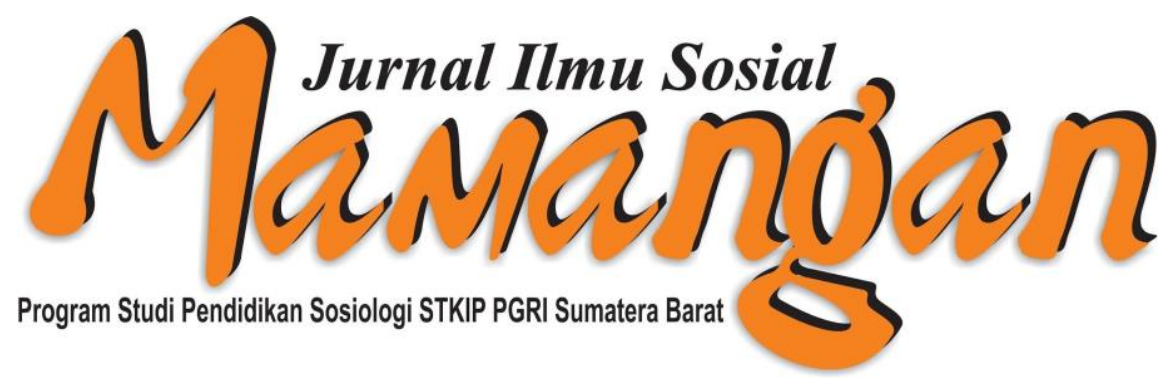

Mamangan Social Science Journal,

Volume 9, Issue 2, July- December , 2020

\title{
TITLE OF ARTICLE
}

Author (s) : Ithvi Marhamah

Source : Jurnal Ilmu Sosial Mamangan, Volume 9, Issue 2, July- December , 2020

Publisher : : Sociology Education Laboratory, STKIP PGRI West Sumatra

\section{To Cite This Article:}

Ithvi Marhamah, 2020. Community and City Government Participation in Coastal Coastal Area Conservation: a study in Pariaman City. Jurnal Ilmu Sosial Mamangan, Volume 9, Issue 2, July- December 90-102, 2020

Copyright (C) 2020,Journal of Mamangan Social Sciences

ISSN: 2301-8496 (Print) \& 2503-1570 (Online)

Sociology Education Laboratory STKIP PGRI West Sumatra 


\title{
Community and City Government Participation in Coastal Area Conservation: a study in Pariaman City
}

\author{
Ithvi Marhamah
}

\begin{abstract}
Irregularities in spatial use that are not in accordance with regional planning resulting in reduced protected and buffer zone space in Pariaman City. The research objective was to analyze the causes of the deviation in spatial use from the point of view of the sustainability of the coastal area in Pariaman City. The research method is a combination of qualitative research methods with quantitative research methods using a spatial approach using geographic information systems (GIS). The results show that the harmonization analysis between Law 26 of 2007 article 5 and Law 1 of 2014 article 9 and RTRW are appropriate: Coastal areas are used as protected and buffer areas, but the use of existing land is not in accordance with the harmonization analysis of the two laws and regulations. By the existence of a built-up area in an area that should be a buffer zone. The participation of the community and city government in the management of the coastal area causes this deviation: Lack of knowledge of residents about the zoning of customary rights over are two contributing factors. The city government which prioritizes the economic development of coastal areas with tourism development threatens the ecology and coastal resources
\end{abstract}

Keyword: Environmental Management, Conservation, Coasta areas, Community participation, Zoning

\section{INTRODUCTION}

Indonesia is an archipelago country that has 17,508, 81,000 km of coastline and vast ocean of about 3.1 million $\mathrm{km}^{2}$. The sustainability of Indonesia's coastal areas, which have enormous wealth, must be preserved by utilizing functions directly adjacent to the sea. Pariaman City is located in the western part of the island of Sumatra, which is directly adjacent to the Indonesian Ocean. As a lowland area located in the coastal area, Pariaman City has extensive marine waters and includes biodiversity both ecologically and economically.

Coastal areas which are rich in biodiversity, need to be regulated with a sustainable policy by taking into account geographical conditions, population distribution, and other potential and strategic aspects. The results of this spatial planning arrangement are expected to be able to realize sustainable development (Sustainable development) which can integrate the pillars of the economy, socioculture, environment and building arrangement.
Pariaman City has carried out many developments in the coastal area, both on existing development and new land for various purposes such as: education, health, offices, tourism, housing etc. So far, the development carried out by the government has emphasized economic growth but ignores environmental aspects. Because it places human needs above nature, causing the potential for coastal areas to overlap.

According to Law No. 26 of 2007 concerning Spatial Planning, coastal area management planning can provide economic and ecological benefits.

Odum (1976) argues that land use planning for coastal areas must be linked to ecological overall planning in the form of environmental zoning. Environmental zoning planning can be grouped into 3 categories of use as follows:

1. Zone for conservation

2. Zone for preservation

3. Zone for intensive development

Environmental planning with this complex zoning system requires support from various authorities, especially decision 
makers, with the expected results more likely to be achieved. The successful application of this zoning system requires two main supporting infrastructure, that is (Kesry, 1992); First, there is a flow of legislation and a strong administrative organization in the government to be able to create maintain and have power in these regulations and licensing so that the integrity of these zones can be maintained. Second, there must be a method of zoning determination based on this zoning decision, this decision should not be based solely on political capability, but also based on actual considerations that are accurate to economic, ecological and aesthetic factors.

Although progress at the level of laws and regulations in the coastal area of Pariaman City is not in accordance with applicable regulations, such as: Settlements that continue to increase every year, overlapping developments due to conflicts of interest. If this is allowed to do so, there will be an imbalance in the coastal area and there is a concern that there will be scarcity of biological resources and flood disasters due to land closure for water absorption, as well as uncontrolled conflicts because there are no restrictions on the use of previously utilized areas. That is why it is necessary to manage and preserve the zoning direction of coastal areas and the participation of the community and government in environmental management so that the natural resources of Pariaman City are maintained and sustainable.

Law No. 1/2014 on the management of coastal areas and small islands. Community participation in managing coastal areas is regulated by Regulation of the Minister of Marine Affairs and Fisheries Number 40 / PERMEN-KP / 2014 concerning community participation and community empowerment in managing coastal areas and small islands. This regulation is the basis for an active role in the management of coastal areas.

\section{RESEARCH METHODS}

The research method used is a combination of qualitative research methods and quantitative research methods with a spatial approach that uses a geospatial information system (GIS). This study uses two types of data, namely primary data and secondary data. Primary data were obtained by conducting physical observations and in-depth interviews using research guidelines, while secondary data were obtained from data from agencies related to coastal area management.

\section{Zoning Determination the Procedure}

Input data needed in this zoning method are soil type maps, topographic maps, rainfall maps, coastal border maps, flood hazard maps, settlement maps and beach dynamics maps. By using the scoring method to determine the function of the area based on Law No. 26 of 2007 article 5 and the level of conformity based on Law No. 1 of 2014 article 9 of the two laws we overlay to determine the zoning that fits the criteria. Then compare it with the RTRW and existing land use to obtain zoning compatibility to see whether or not the direction of coastal area management is appropriate.

\section{a. Zoning Based on Law No. 26 of 2007 concerning Spatial Planning}

Scoring Process for coastal physical criteria to determine zoning of land suitability based on Ministerial Decree No.837 / KPTS / UM / 11/1980 and No.683 / KPTS / UM / 8/1981 (can still be used because there are no new terms yet). The following scores and function assessments are presented in the following tables:

Table 1. Area Function Score and Assessment

\begin{tabular}{clc}
\hline No & \multicolumn{1}{c}{ Area Function } & Total Score \\
\hline 1. & Protected Area & $>175$ \\
2. & Buffer Area & $125-174$ \\
3. & $\begin{array}{l}\text { Annual Crop } \\
\text { Cultivation Area }\end{array}$ & $<125$ \\
4. & $\begin{array}{l}\text { Seasonal Crop } \\
\text { Cultivation Area }\end{array}$ \\
5. & Settlement Area & $<125$ \\
\hline Source: & Ministerial Decree No.837 / KPTS / UM / \\
11/1980 and No.683 / KPTS / UM / 8/1981
\end{tabular}


For topographic physical characteristics of described the value of the score as follows; slope class, soil type and bulk rain can be

Table 2. Slope Class and Score

\begin{tabular}{ccccc}
\hline No & Class & & Description & Score \\
\hline 1. & I & $0-8$ & Flat & 20 \\
2. & II & $8-15$ & Ramps & 40 \\
3 & III & $15-$ & Slightly Steep & 60 \\
4 & IV & $24-$ & Steep & 80 \\
5 & V & $>45$ & Very Steep & 100 \\
\hline
\end{tabular}

Source: Ministerial Decree No.837 / KPTS / UM / 11/1980 and No.683 / KPTS / UM / 8/1981

Table 3. Soil Class according to Erosion Sensitivity and Score Score

\begin{tabular}{|c|c|c|c|c|}
\hline No & Class & Type Soil & Description & Score \\
\hline 1. & 1 & $\begin{array}{l}\text { Alluvial, Gley Soil, Planosol, Hidromorf Gray, } \\
\text { laterite Groundwater }\end{array}$ & Insensitive & 15 \\
\hline 2. & II & Latosol & Less Sensitive & 30 \\
\hline 3 & III & $\begin{array}{c}\text { Brown Forest Soil, Non Caltic Brown, } \\
\text { Mediterranean }\end{array}$ & Sensitive & 45 \\
\hline 4 & IV & Andesol, Lateric, Grumusol, Pedsol, Pedsoltic & Sensitive & 60 \\
\hline 5 & V & $\begin{array}{c}\text { Regisol, Litosol, Organosol, Renzina11/1980 } \\
\text { and No.6838/1981 }\end{array}$ & Very Sensitive & 75 \\
\hline
\end{tabular}

Source: Ministerial Decree No.837 / KPTS / UM / 11/1980 and No.683 / KPTS / UM / 8/1981

Table 4. Average Daily Rainfall Intensity and Score Score

\begin{tabular}{ccccc}
\hline $\mathbf{N}$ & Class & $\begin{array}{c}\text { Interval } \\
\text { (mm / day) }\end{array}$ & Description & Score \\
$\mathbf{0}$ & & $0-13.6$ & Very low & 10 \\
\hline 1. & I & $13.6-20.7$ & Low & 20 \\
2. & II & $20.7-27.7$ & Moderate & 30 \\
3 & III & $27.7-34.8$ & High & 40 \\
4 & IV & $>34.8$ & Very High & 50 \\
5 & V & Source: Minister of Agriculture Decree No.837 / KPTS / UM / 11/1980 \\
\hline \multicolumn{5}{r}{ and No.683 / KPTS / UM /8/1981 }
\end{tabular}

b. Zoning Be $r$ based on Law No. 1/2014 concerning Management of Coastal Areas and Small Islands. The

Criteria used in determining the suitability of utilization zones such as

Table 5. Zones and Conformity Scoring

\begin{tabular}{|c|c|c|c|c|c|c|}
\hline No & Zones & Criteria & Parameters & Score & Weight & $\begin{array}{c}\text { Score } \\
\text { (number } \\
\text { x weight) }\end{array}$ \\
\hline \multirow{5}{*}{1.} & \multirow{5}{*}{ Protect } & Coastal & $\begin{array}{l}\text { - } 100-200 \mathrm{~m} \text { from tide } \\
\text { point to land }\end{array}$ & 2 & 20 & 40 \\
\hline & & Border & $\begin{array}{l}\text { - } 0-<100 \mathrm{~m} \text { from tide point } \\
\text { to land area }\end{array}$ & 0 & 0 & 0 \\
\hline & & & - Occurred abrasion on & 2 & 10 & 20 \\
\hline & & Disaster- & the coast & 0 & & \\
\hline & & prone & - Not abrasion & 2 & 10 & 20 \\
\hline
\end{tabular}

coastal boundaries, disaster-prone areas, dynamics of beaches and settlements, zones and suitability scoring can be seen in Table 5 below. 


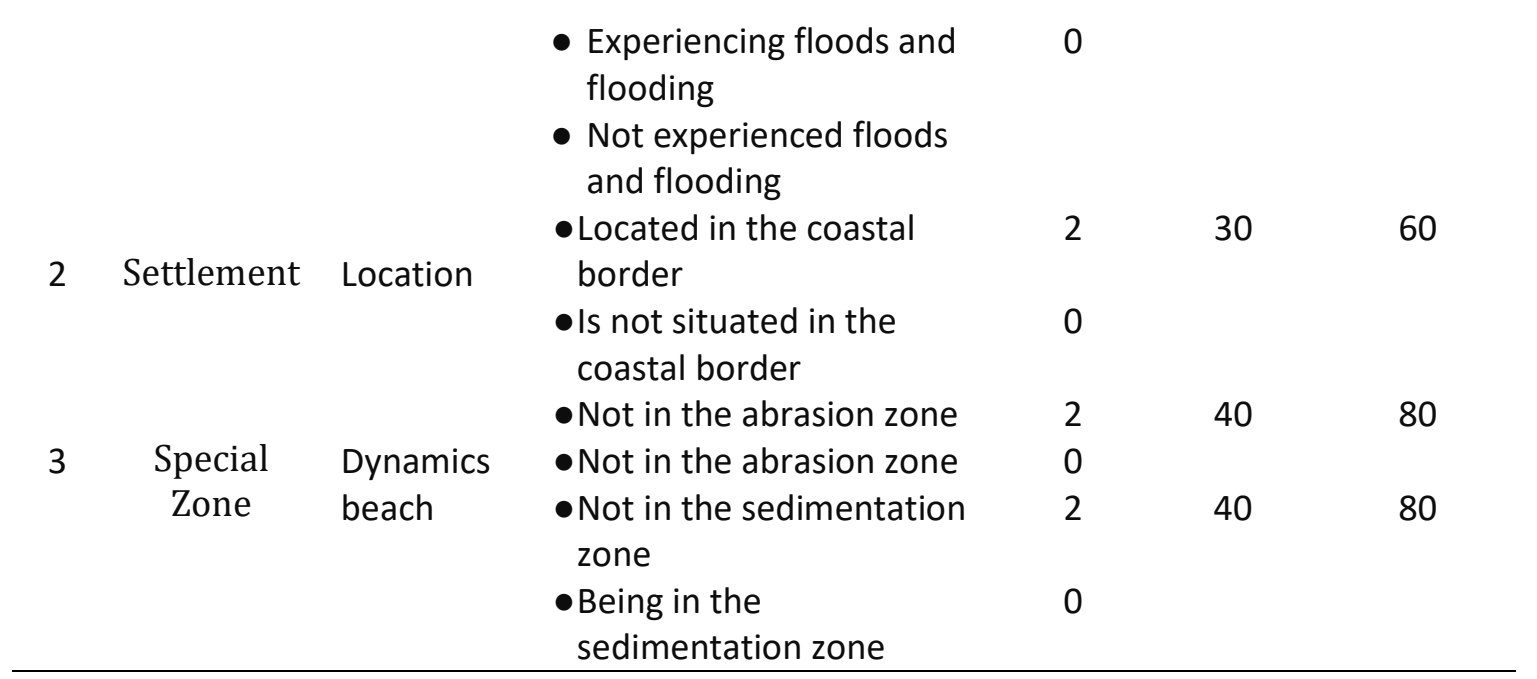

Source: Kepmen No. 34 of 2002

From the score in table 5 is multiplied by the weighted score with the formula: $\mathrm{N}=($ Protected Score x 10\%) + (Utilization Score x 60\%) $+($ Special Score X 30\%) So that the total score that can be done for evaluation is obtained. Evaluation of research results can be seen in table 6 below.

Table 6. Criteria Level of Conformity

\begin{tabular}{lcl}
\hline \multicolumn{1}{c}{ Criteria Level of Conformity } & Value & \multicolumn{1}{c}{ Remarks } \\
\hline Verys1) & $>80-100$ & $\begin{array}{l}\text { This area is supportive and very } \\
\text { feasible to be developed }\end{array}$ \\
$\begin{array}{l}\text { Suitable for Utilization } \\
\text { (Suitable for utilization (S2) } \\
\text { Not suitable }\end{array}$ & $\geq 60-80$ & $\begin{array}{l}\text { Eligible to be developed but with } \\
\text { certain conditions } \\
\text { Should be allocated for protected } \\
\text { zones }\end{array}$ \\
\hline
\end{tabular}

Source: Kepmen No. 34 of 2002

\section{Community and Government \\ Participation Analysis Using Qualitative Descriptive Methods}

Community and government participation is analyzed in the management and preservation of coastal areas to describe phenomena in good and sustainable management of coastal areas in Kota Pariaman. Primary and secondary data analyzed were used to draw conclusions from each research problem formulation.

To produce valid qualitative data in qualitative research, interview data collection techniques are used, conducted with the format of "in-depth interviews", which is an interview without alternative answer choices and is carried out to explore information from an informant where the researcher has prepared several structured questions for research guidance, then developed so that the answers obtained can include all variables and new things that are encountered in the field (Afrizal, 2014). The research design can be seen in Figure 1.

\section{RESULTS AND DISCUSSION}

a. Zoning based on Law 26 of 2007 Article 5 Concerning Spatial Planning

Based on the overlay results of 3 types of maps, namely (soil type, rainfall and slope), the result is a map of the function of the area. Based on the analysis of the function map of the Kota Pariaman area, there are 4 results of the area function, namely seasonal crop cultivation areas and settlements, annual cultivation areas and buffer areas and protected areas.In the coastal area of Pariaman City, there are 2 area functions, namely seasonal crop 
cultivation areas and settlements in yellow, and annual cultivation areas in green. The results of the function of the area can be seen in Figure 2 below.

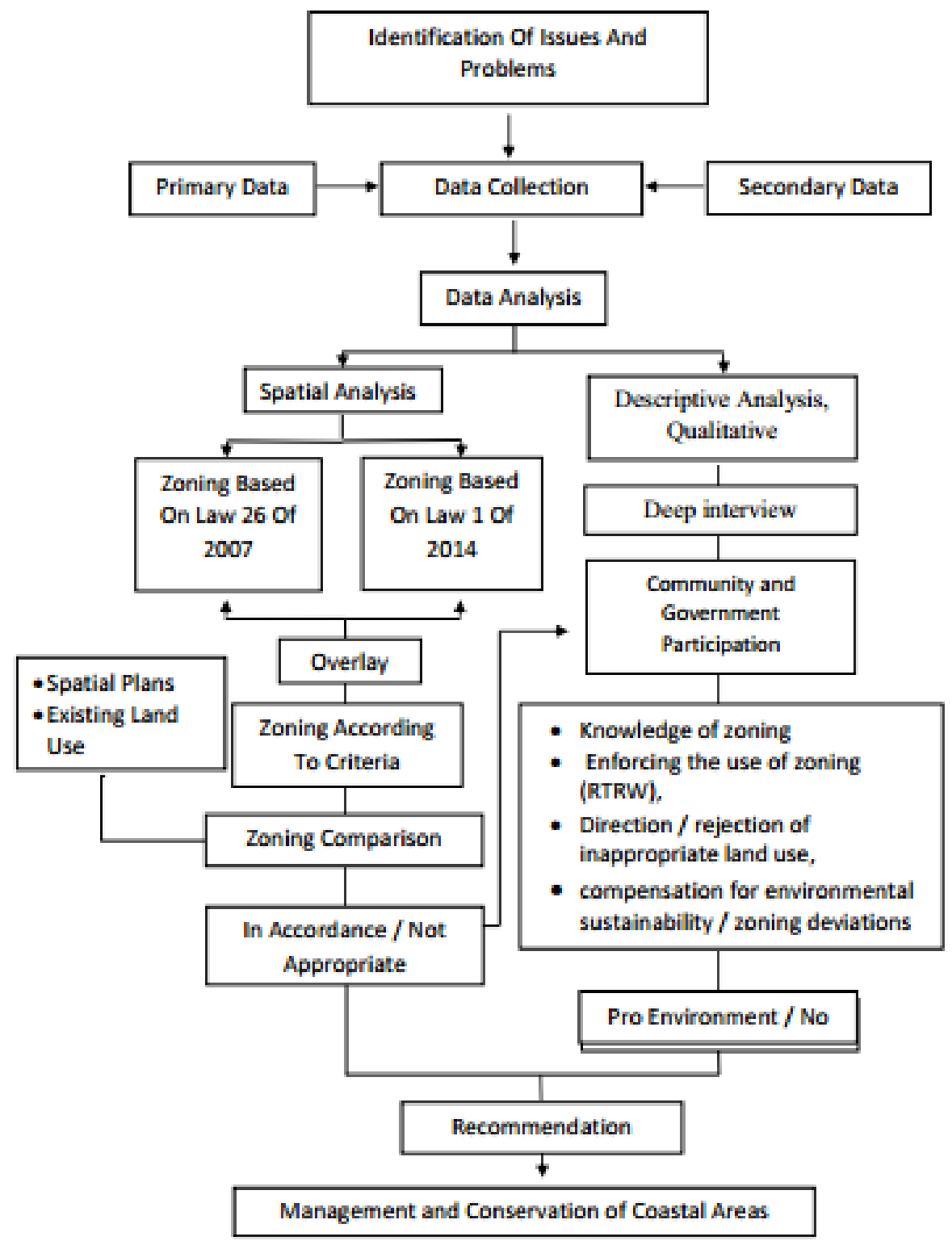

Figure 1. Research Design

From Figure 3 above, it can be seen that the level of land suitability with a score of $>80-100$, S1 category, this means that it is very suitable to be used where this area supports and is feasible to develop as many as 3 locations or $21.5 \%$, Kelurahan Karan Aur, Kelurahan Lohong and Kelurahan Pasir. These 3 kelurahan are a strategic area of Kota Pariaman where there are various human activities such as markets, tourist attractions, housing, education, health, etc.

The land suitability level with a score of $>60-80$, category S2, this area is suitable for use where this area is feasible to develop but with certain conditions as many as 11 locations or 78.5\%, namely; Desa Pasir Sunur, Marunggi, Taluak, Pauh Barat, Ampalu, Apar, Manggung, Naras Hilir, Narasi-1, Balai Naras, and Padang BirikBirik. The thing that distinguishes it from the previous $\mathrm{S} 1$ or 3 kelurahan is that this area is prone to abrasion which results in damage along the coast such as reduced and damaged mangroves, the removal of coastal trees, the destruction of residential areas which if not addressed quickly results in 
erosion and damage to the coastal environment. Continually because of that this area must be carried out in a proper management in accordance with the criteria for regional development.
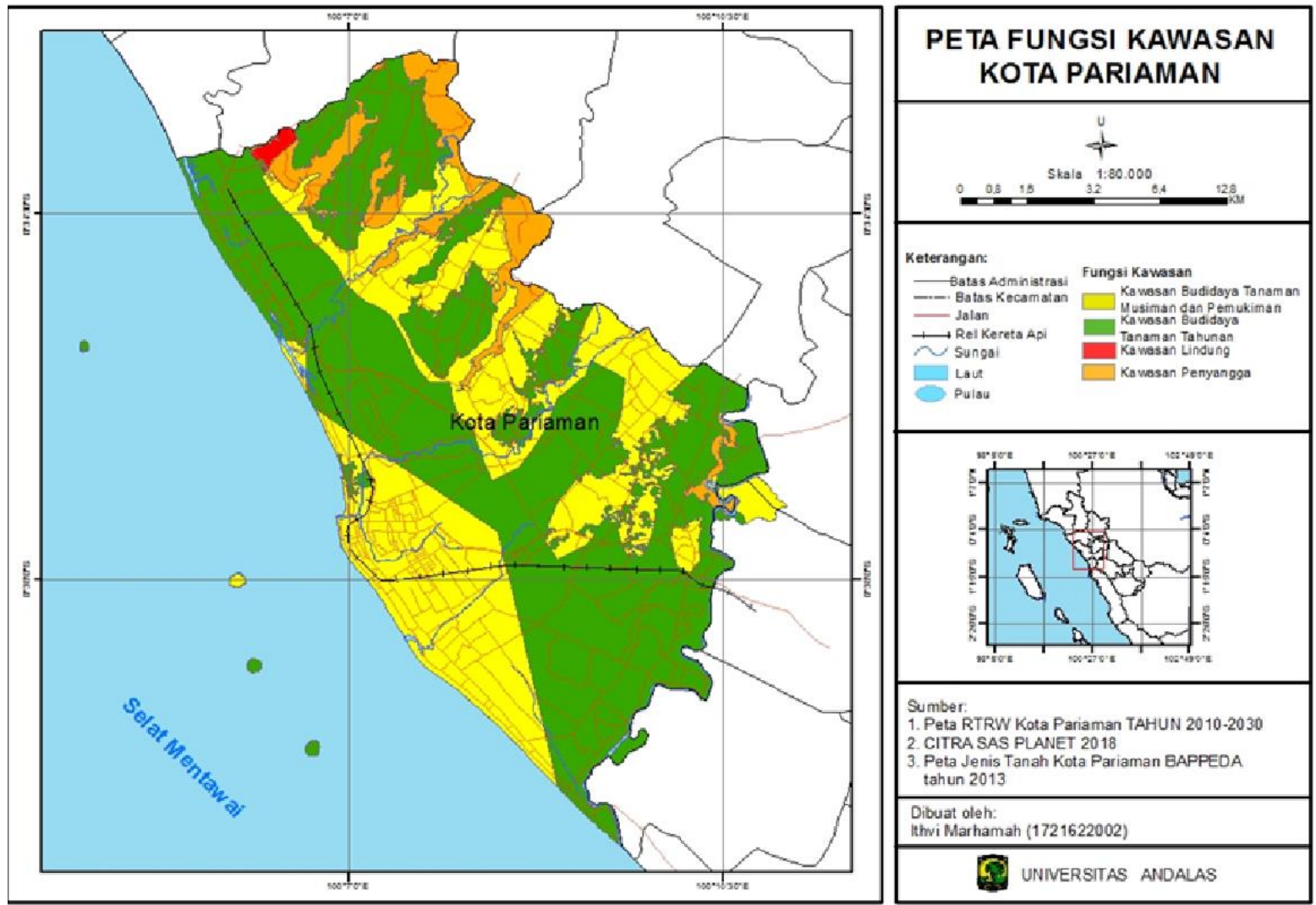

Figure 2. Zoning Law No. 26 of 2007 Article 5 concerning Spatial

b. Zoning Based on Law 1 of 2014 Article 9 concerning Management of Coasts and Small Islands

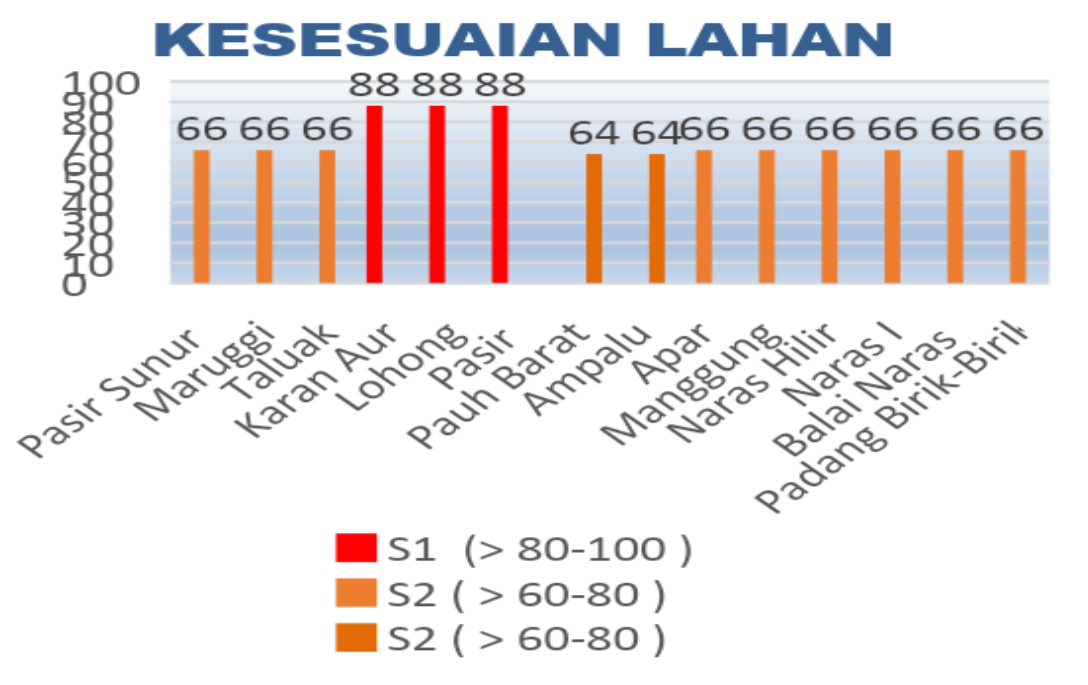

Figure 3. Land suitability 
For spatial location according to the Regional Regulation on the Zoning Plan for Coastal Zone and Pulau Kesil (RZWP-3-K) West Sumatra Province No.2 of 2018, Concerning the 2018-2038 Coastal Zone and Small Island Zoning Plan, West Sumatra Province, in details of the area and coordinates Conservation area. The coastal area of Pariaman City is included in the marine conservation area, namely the tourist park of Pieh Island waters and its surroundings and as explained in the KKPD Pariaman City, that is the conservation of turtles, mangrove forests and small islands in Pariaman City. Environmental conservation activities carried out, such as the delivery of turtle eggs by the community to be incubated at the KKPD Kota Pariaman, planting mangroves from various activities both from the government, education, environmentalists and the preservation of small islands that are not open to the public in order to minimize the impact of damage island. To see the results of land suitability for the coastal area of Kota Pariaman, it can be seen in Figure 4 below.
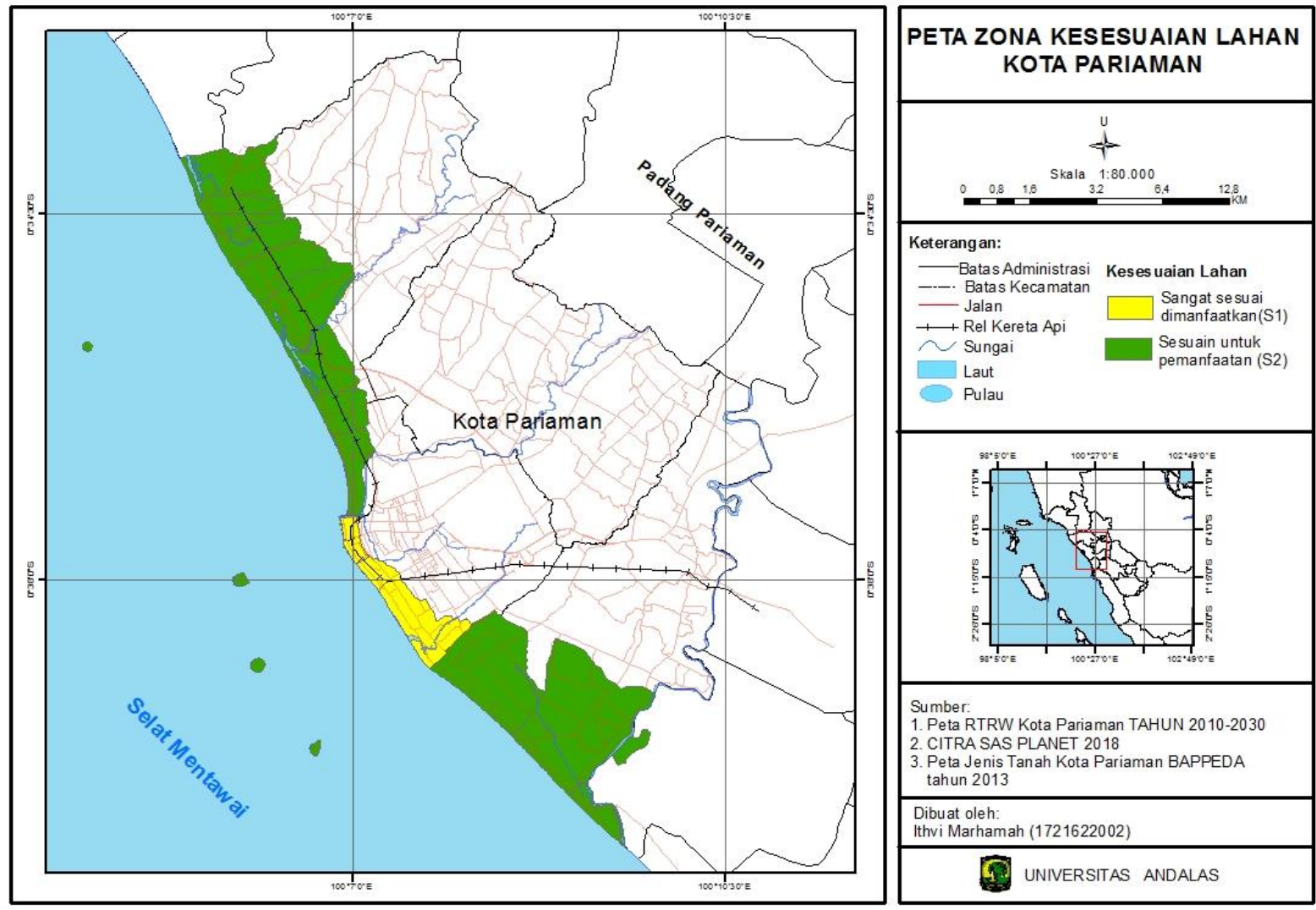

Figure 4. Zoning Law No.1 of 2014 Article 9 concerning Management of Coasts and Small Islands as a

\section{c. Result of the Harmonization of Zoning from 2 Laws (Law No. 26 of 2007 article 5 and Law No. 1 of 2014 article 9)}

Results of the Zone analysis of 2 Law (Law No. 26 of 2007 article 5 and Law No. 1 of 2014 article 9) obtained zoning that can accommodate the Law. From the zone obtained, the analysis is then synchronized with the equations of the resulting zones. The synchronization is done as a synchronization step for the zoning provisions of the two different regulations. For the conservation zone, it is equated with a buffer zone which has almost the same meaning, which is to protect.

Then for the utilization zone it is equated with the cultivation zone but added with the provisions of the results of the analysis based on Law no. 1/2014 concerning the management of coastal areas and small islands used or coastal development in Kota 
Pariaman is a development that is limited in nature, which means that it can be developed with certain terms and conditions. The results of zoning based on Law 26 of 2007 article 5 and Law 1 of 2014 article 9 are overlaid with the mangrove distribution area and the minimum beach boundary in accordance with Law 51 of 2016 (100 meters minimum limit) of coastal boundaries. To maximize the coastal land zoning planning of Pariaman City for a sustainable area guideline. The zoning results as a reference for the development of the coastal area of Pariaman City can be seen in Figure 5 below.
Based on the map of the zoning results, it can be estimated what activities can be carried out in these zones, especially in the context of developing the coastal area of Pariaman City. For the buffer zone, this activity is more focused on coastal protection and protection, such as the conservation of natural beaches by planting mangroves, which are now dead and converted into other functions. Whereas for limited use areas it can be used for agricultural and plantation cultivation, in this zone it is highly discouraged to carry out cultivation which is built in nature (settlement, trade and the like).

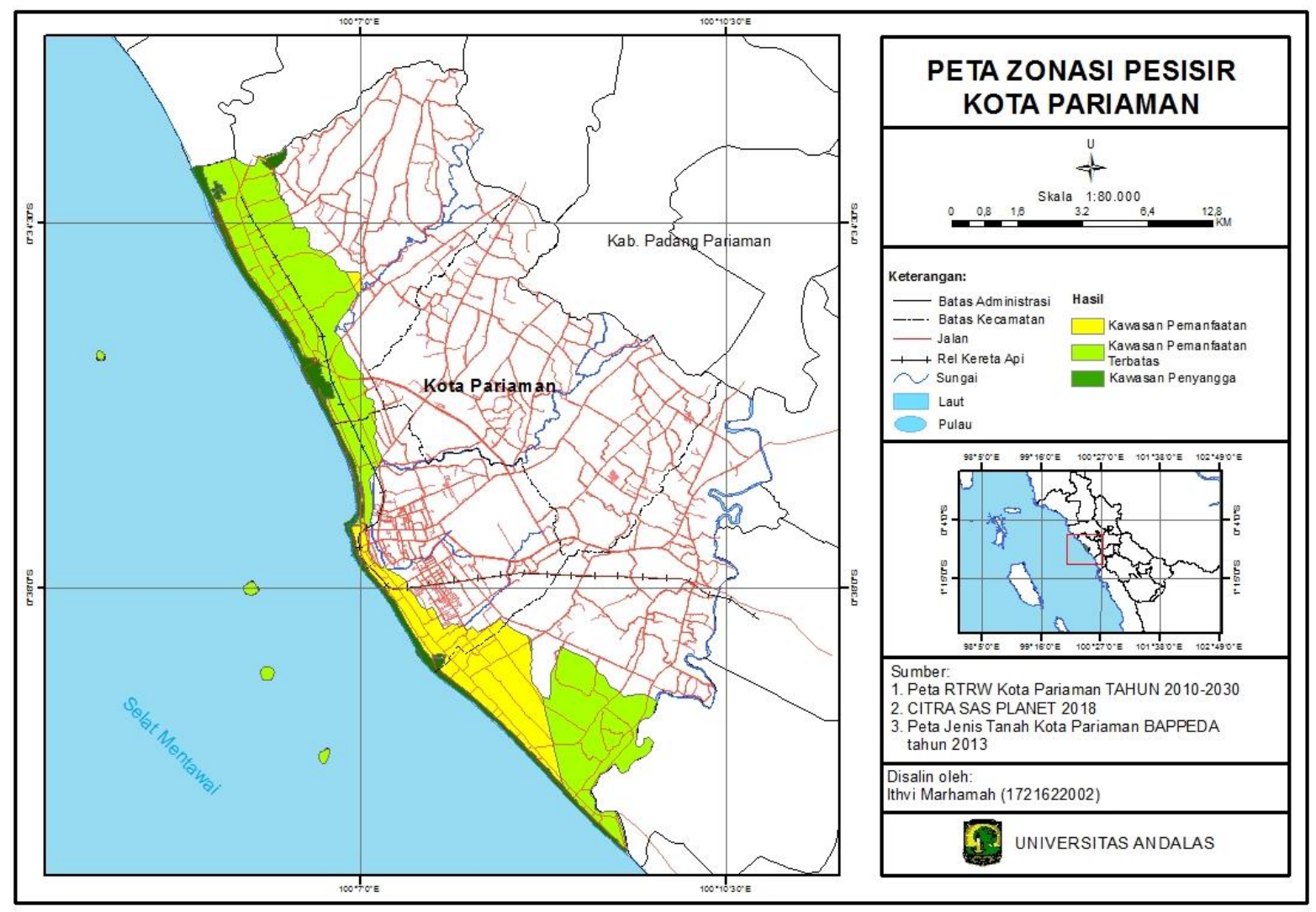

Figure 5. Zoning Map Analysis Results 2 Law

\section{d. Zoning Comparison}

2) Results 2 Laws (Law No. 26 of 2007 article 5 and Law No. 1 of 2014 article 9) with RTRW

Comparison of zoning results from 2 laws (Law 26 of 2007 article 5 and Law 1 of 2014 article 9) with RTRW is very suitable, there is no difference in zoning that will be allocated in the mainland part of the coastal area of Pariaman City.

Based on the RTRW Map for Pariaman City above, most of the coastal areas planned in the RTRW spatial pattern are in accordance with the zoning results of two laws (Law 26 of 2007 article 5 and Law 1 of 2014 article 9). From this we can see that there is no difference in the designation of the zoning 
results and the RTRW plan. The green and dark green colors in the RTRW coastal area are intended for coastal boundaries and coastal green spaces. And this equation can also be seen in the zoning results of two laws for dark green in the part of the coastal area which are designated for buffer zones that function for protected areas and limited cultivation that cannot be used for built-up areas. By looking at the results of this comparison, it is clear that the similarities between the zoning results of the two laws with the RTRW where the designation of the coast is used for protection and buffer areas that take into account the suitability of land in the utilization of the coastal areas of Pariaman City.

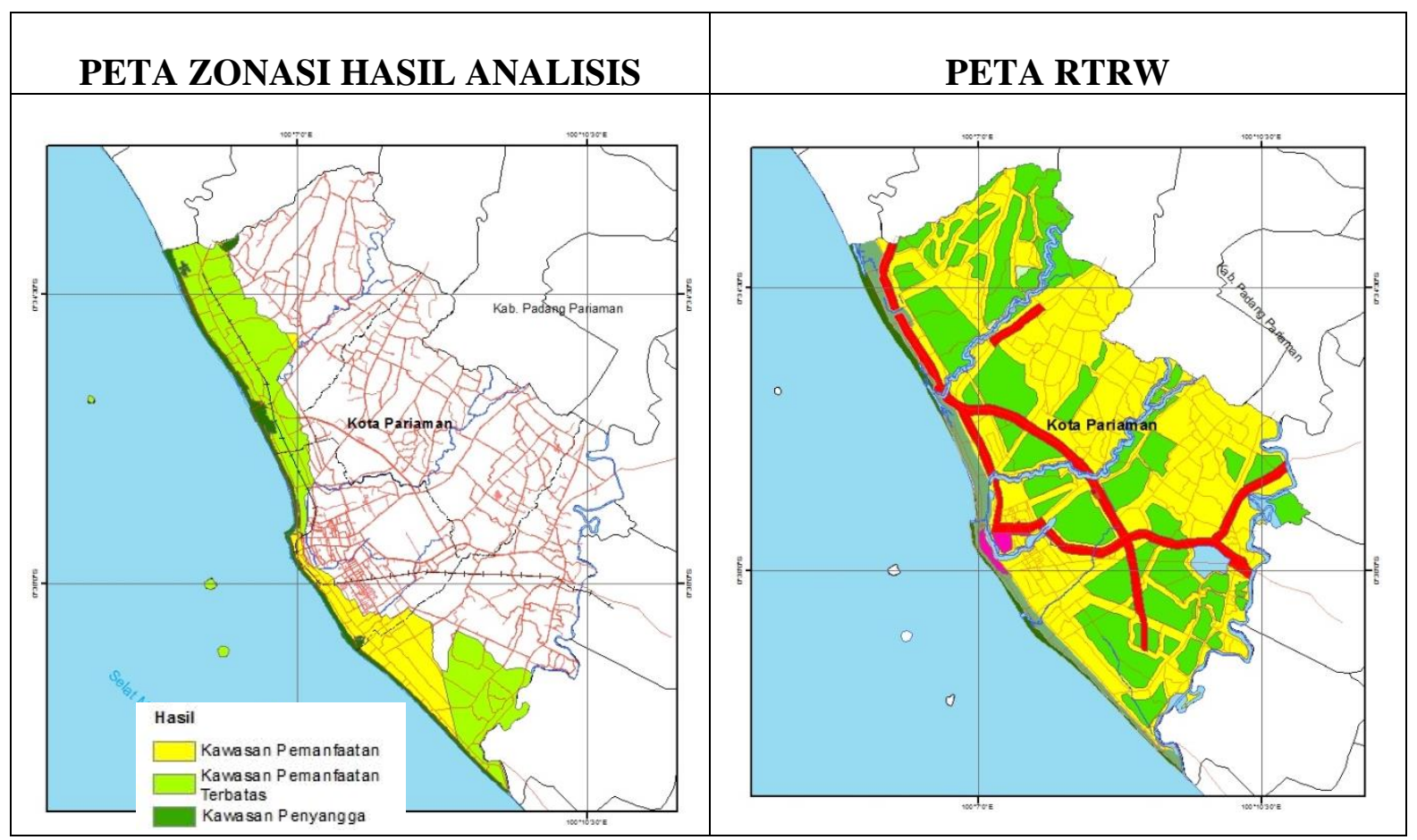

Gambar 1. Perbandingan Zonasi 2 UU dengan RTRW

2) Comparison of Zoning Results from 2 Laws (Law No. 26 Year 2007 Article 5 and Law No. 1 Year 2014 Article 9) with the Use of Existing Land.

From the comparison results in Figure 7 it can be seen, for the sign in the red circle there is an area that should have been converted for limited use such as green beaches or agriculture instead into an area. Utilization, namely settlements along the coast of Pariaman City. The results of the comparison of the map results from 2 of these Law Policies are the number of existing land uses that are not in accordance with the designation.

It should be on the coastal land, that is the protected and buffer areas designated as coastal borders and green beaches but become residential areas. Based on the existing results for the last 5 years, in 20142018 there were 56 new settlements along the coast of Pariaman City. Community settlements are located in the shoreline area which is communal land. So it can cause flooding in coastal areas due to narrowing of the run off or the lack of water catchment areas in these coastal areas.

From this discussion, it can be concluded that the results of the harmonization analysis of 2 laws (Law No. 26 of 2007 article 5 and Law 1 of 2014 article 9) with RTRW are appropriate where coastal areas are used as protected and buffer areas, while comparisons with existing land uses are not appropriate because there are builtup area in a coastal buffer zone in Pariaman City. 


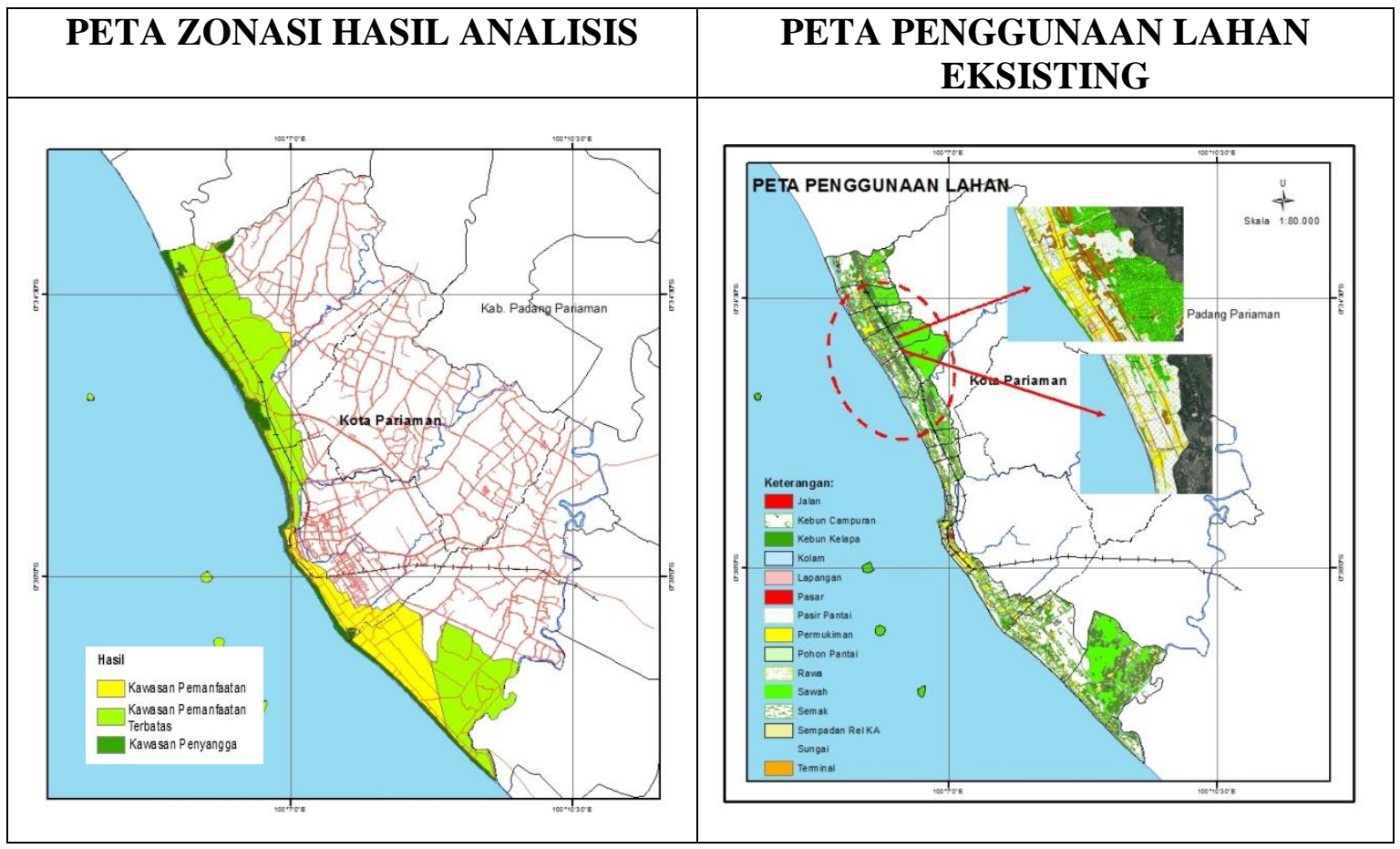

Figure 7. Comparison of Zoning 2 Laws with Existing Land Use

From the comparison results in Figure 7, it can be seen, for the sign in the red circle, there are areas that were converted which should have been for limited use, such as green beaches or agriculture, instead into utilization areas, namely settlements along the coast of Pariaman City. The results of the comparison of the map results from 2 of these Law Policies are the number of existing land uses that are not in accordance with the designation. It should be on the coastal land, namely the protected and buffer areas designated as coastal borders and green beaches but become residential areas. Based on the existing results for the last 5 years, in 2014-2018 there were 56 new settlements along the coast of Pariaman City. Community settlements are located in the shoreline area which is communal land. To see the current state of land use, it can be seen in Figure 8 below.

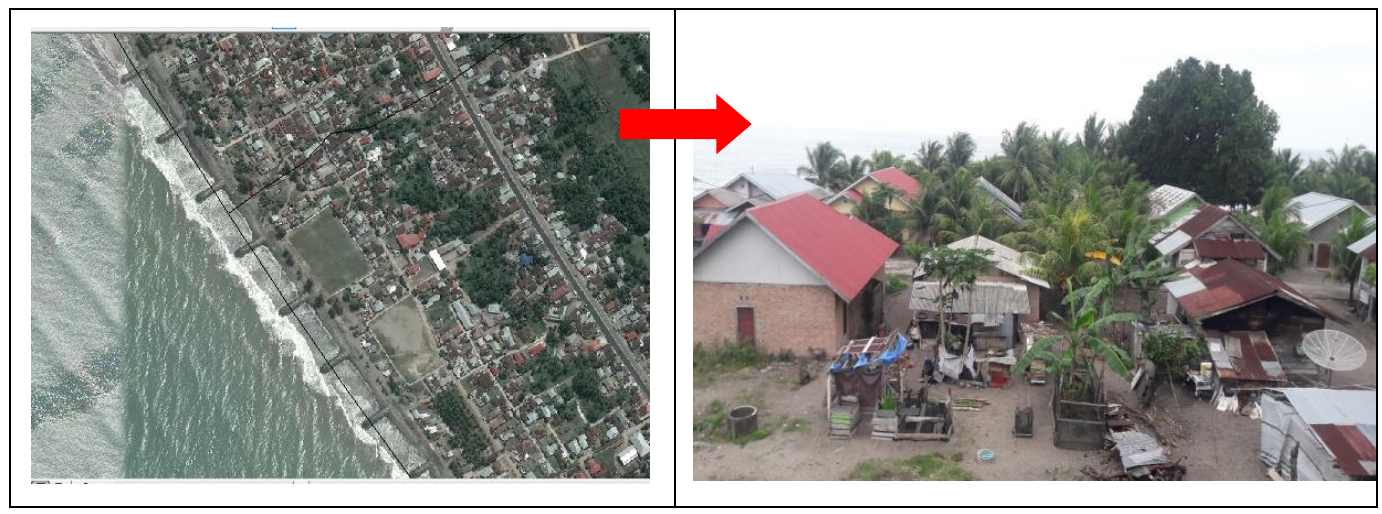

Figure 8. Field conditions on existing land use

From this discussion it can be concluded that the results of the harmonization analysis of 2 laws (Law No.
26 of 2007 article 5 and Law 1 of 2014 article 9) with RTRW are appropriate where coastal areas are used as protected and 
buffer areas, while the comparison with the existing land use is not suitable because there is a built-up area in the coastal buffer zone in Pariaman City.

\section{Community Participation in Conservation and Environmental Management of Coastal Areas}

Results of in-depth interviews with 5 informants who live in the coastal areas of Pariaman City show that knowing the coastal areas they live in are conservation and coastal tourism areas. But they still build houses in that area. Their reason is that their land is inherited from their parents from generation to generation, free land or also known as inheritance land.

The residents got permission from the village government and ninik mamak to build buildings. The residents stated that they did not get direction and were rejected by the village government in establishing a village government in constructing buildings and providing environmental compensation for the sustainability of the coastal areas.

Apart from that, the residents also have a title to the land and a PRONA program. Of course with this certificate the basis for the residents to build stronger buildings. The government provides ownership certificates for coastal areas in contrast to the RTRW for Pariaman City.

According to the city government, enforcing the RTRW through IMB permits, giving directions or rejecting it if it is not in accordance with the RTRW. But in reality this is not done, maybe this is because the residents provide environmental compensation as a contribution to the IMB arrangement as a technical and administrative requirement.

Areas where there are no deviations are not the result of effective management but are influenced by unsafe topography for settlements and the land belongs to the State designated as tourist areas. Deviations also occur due to the government policy of Pariaman City to develop coastal areas for tourist destinations that are very profitable for the income of Pariaman City, such as marine tourism, educational tours, mangrove parks etc. For the implementation of this policy, there are a variety of different stakeholders even though it is for one purpose of increasing the economy in the tourism sector. The policy of developing coastal areas as a tourist destination creates pressure on the ecology and coastal resources. This has resulted in environmental damage such as damage to mangrove forests in 2 gig tourist spots and grouse beach and mangroves that have been depleted due to weather and climate and lush gardens along the coast.

Based on the description above, there are directions and recommendations in the management and preservation of coastal areas as follows:

a. Conservation of coastal areas

1) Increase strict policies on conservation and preservation of coastal areas that have been established by RZWP3K and other areas that must be protected for the sustainability of coastal areas for conservation right on target.

2) Creating special conservation areas and natural beaches, for sedimentation, abrasion and accretion control measures. Such as simple breakwaters such as rocking grid, making beach walls and estuary cliffs.

3) The limitation of cultivation areas in buffer areas is generally for built-up areas in coastal areas which are supported intusinally and community empowerment.

b. Building community perceptions Management and conservation efforts must begin with knowledge or information by means of announcements, socialization, counseling, direct actions in the management of coastal areas in depth to change people's perspective, foster a sense of belonging and concern for the environment. Lack of attention to environmental preservation of coastal areas is mainly due to the fact that the function of coastal areas is considered unreal for the community due to a lack of knowledge and awareness of the environment for their daily lives. 
c. Community empowerment

Efforts to manage and conserve coastal areas must be followed by community empowerment activities in order to foster community interest and capacity in managing the environment in coastal areas. Community empowerment aims to increase knowledge of the quality and quality of people who care about the environment. Community empowerment increases the economy as well as fosters environmental awareness for economic independence and ensures the sustainability of coastal areas. One form of community empowerment activity is the provision of capital / business assistance.

For example, mangrove management in Apar Village which produces syrup, jam and kalamai products from processed mangrove fruit. Even though there is still 1 village that manages mangrove fruit, at least there are several villages along the coast that can manage mangroves. Even though each village does not have mangroves, some of these villages are still included in several villages. So that they can empower the community in managing mangroves together based on the division of the village. Taking yields from mangroves, replanting mangroves can not only increase mangrove production but also stabilize and increase the distribution of mangroves in Pariaman City, both as a container and as a protection for coastal areas. This community empowerment becomes the right policy liaison between the community and the government in managing and preserving the environment in the coastal area of Pariaman City.

\section{CONCLUSION}

There is a gap between the development of statutory regulations and the realization of statutory regulations in the preservation of coastal areas in Kota Pariaman. Regional regulations on RTRW for Kota Pariaman. In accordance with Law 26 of 2007 article 5 and Law 1 of 2014 article 9, however, the use of existing land is not in accordance with statutory regulations, because there is a built-up area in the coastal buffer zone of Pariaman City where there should be no buildings.

The participation of citizens and government in the management and preservation of coastal areas is the cause of this gap. The residents build in the area and the behavior of the residents is not entirely anti-environmental. The residents do greening around the residence, throw garbage in its place, but they build buildings in the area where buildings should not be built. The reason is their claim to customary land rights over land and they are not aware that the area is a protected area. On the other hand, the city government does not try to prevent them from building buildings, because the government focuses on economic development in coastal areas. In the absence of conformity, there must be a firm policy in controlling the use of coastal space, coordination of the City government and the community in increasing synergy in sustainable protection so as not to threaten the ecology and resources on the coast of Pariaman City.

\section{REFERENCES}

Afrizal. (2014). Metode penelitian kualitatif: sebuah upaya mendukung penggunaan penelitian kualitatif dalam berbagai disiplin ilmu. PT RajaGrafindo Persada.

Birawa, C., \& Sukarna, R. M. (2016). Zona Ekowisata Kawasan Konservasi Pesisir di Kecamatan Katingan Kuala, Kabupaten Katingan, Provinsi Kalimantan Tengah Melalui Pendekatan Ekologi Bentang Lahan. Jurnal Ilmu Kehutanan, 10(1), 19-32.

Dahuri, R., Rais, J., Ginting, S. P., \& Sitepu, dan M. J. (2001). Pengelolaan sumberdaya wilayah pesisir dan lautan secara terpadu. PT. Pradnya Paramita. Jakarta, 328.

Efendy, M. (2009). Pengelolaan Wilayah Pesisir Secara Terpadu: Solusi Pemanfaatan Ruang, Pemanfaatan Sumberdaya Dan Pemanfaatan Kapasitas Asimilasi Wilayah Pesisir 
Yang Optimal Dan Berkelanjutan. Jurnal Kelautan: Indonesian Journal of Marine Science and Technology, 2(1), 81-86.

Ifiginia, Pudyastuti, P. S., Kuswartomo, \& Hidayati, N. (2018). The analysis of backwater impact on the increasing of floodwater level in Palu River. AIP Conference Proceedings, 1977(1), 50007.

Kahfi, A. (2015). Peran Serta Masyarakat Dalam Pengelolaan Lingkungan Hidup. Jurisprudentie: Jurusan Ilmu Hukum Fakultas Syariah Dan Hukum, 2(2), 4152.

Lautetu, L. M., Kumurur, V. A., \& Warouw, F. (2019). Karakteristik Permukiman Masyarakat Pada Kawasan Pesisir Kecamatan Bunaken. Spasial, 6(1), 126-136.

Manaf, M. (2015). Analisis Pemanfaatan Ruang Di Wilayah Pesisir Kecamatan Bontoharu Kabupaten Kepulauan Salayar. Plano Madani: Jurnal Perencanaan Wilayah Dan Kota, 4(2), 10-21.

Nugroho, I., \& Dahuri, R. (2016). Pembangunan Wilayah: Perspektif ekonomi, sosial dan lingkungan. LP3ES.

Pramudiya, A. (2008). Kajian pengelolaan daratan pesisir berbasis zonasi di Provinsi Jambi. Program Pascasarjana Universitas Diponegoro.
Rositasari, R., \& Rahayu, S. K. (1994). Sifatsifat estuari dan pengelolaannya. Oseana, 19(3), 21-23.

Salim, A. R. (2011). Kajian Pemanfaatan Ruang Kawasan Pesisir Kabupaten Bone Bolango Yang Berwawasan Lingkungan (Studi Kasus Desa Botubarani Dan Desa Huangobotu). Jurnal Ilmu Lingkungan, 9(1), 39-46.

Tuwo, A. (2011). Pengelolaan ekowisata pesisir dan laut: pendekatan ekologi, sosial-ekonomi, kelembagaan, dan sarana wilayah. Brilian Internasional.

Waluyo, A. (2014). Permodelan Pengelolaan Wilayah Pesisir Dan Pulau-Pulau Kecil Secara Terpadu Yang Berbasis Masyarakat (Studi Kasus Di Pulau Raas Kabupaten Sumenep Madura). Jurnal Kelautan: Indonesian Journal of Marine Science and Technology, 7(2), 75-85.

Winanto, T., \& Suparno, S. (2010). Kajian Kondisi Terumbu Karang dan Strategi Pengelolaannya di Suaka Pesisir Batang Gasan, Kabupaten Padang Pariaman, Sumatera Barat. Sains Akuatik: Jurnal Ilmiah Ilmu-Ilmu Perairan, 13(2). 